\title{
Market civilisation meets economic nationalism : the discourse of nation in Russia's modernisation
}

\section{Kangas, Anni}

2013-05-22

Kangas , A 2013 , ' Market civilisation meets economic nationalism : the discourse of nation in Russia's modernisation ' , Nations and Nationalism , vol. 19 , no. 3 , pp. 572-591 . https://doi.org/10.1111/nana.12

http://hdl.handle.net/10138/42480

https://doi.org/10.1111/nana.12023

submittedVersion

Downloaded from Helda, University of Helsinki institutional repository.

This is an electronic reprint of the original article.

This reprint may differ from the original in pagination and typographic detail.

Please cite the original version. 
Market civilisation meets economic nationalism:

the discourse of nation in Russia's modernisation

Anni Kangas

School of Management (International Relations)

33014-University of Tampere, Finland

anni.kangas@uta.fi

November 2013 


\section{Abstract}

This article examines how the discourse of nation functions as a mechanism furthering the expansion of a neoliberal market civilization in Russia. It contributes to discussions that have challenged the assumed mutual exclusivity of economic nationalism and neoliberalism. The article develops its argument in the context of the idea of contemporary international society as a market civilization characterised by an adaptation to and adoption of neoliberal standards by states. The ongoing modernisation project in Russia illustrates the workings of such standards, as exemplified by the project for an innovation city in Skolkovo, in the Moscow metropolitan area. Building on an analysis of the Skolkovo debate, the article agues that there is no inherent contradiction between economic nationalism and neoliberalism. Rather, the nation is an important symbolic system that produces a cultural susceptibility to and a discursive field for the introduction of neoliberal standards of market civilization in Russia.

\section{Introduction}

This article argues that economic nationalism and neoliberalism do not form a contradiction, but are productively intertwined in contemporary Russian political thought and practice. By scrutinising how the discourse of nation functions within a flagship project of Russia's modernisation - the plan to construct a techno-citadel in the Moscow suburb of Skolkovo - the article challenges the idea that economic nationalism is an anachronistic phenomenon in an era commonly characterised as that of globalising markets and declining nation-states (see also Pickel 2005: 1). It argues that nationalism remains an important part of the (proverbial) era of globalisation - not only in the sense of 'governments ... using economic policy to serve national goals' (Goff 2005: 183) but also 
in the sense of the discourse of nation actually assisting the expansion of the market civilisation. It is this latter aspect that this article is interested in. It takes as its starting point the presupposition that 'nationalism is not only compatible with liberal capitalism; it can serve as an agent in its expansion, most especially in opening societies and sectors previously isolated from global market forces' (True 2005: 204). The discourse of nation continues to provide an important mechanism for producing a cultural and historical susceptibility to neoliberal standards in Russia.

This article is structured as follows: the first section discusses the 'new research agenda of economic nationalism' which has criticised the widespread juxtaposition of economic nationalism and neoliberalism. The focus then turns to the debate on market civilisations as the overarching form of contemporary international society, characterised by the rise of the market as the primary institution and a neoliberal ethos that would permit no barrier to market forces. The third section moves on to analyse the Russian debate on the construction of an innovation city in Moscow's Skolkovo suburb. This case is an illustration of the Russian drive to make the country measure up to the standards of market civilisation and of the ways in which the discourse of nation is taken up in this context.

\section{Approaches to economic nationalism}

Economic nationalism and neoliberal globalisation are conventionally discussed as juxtaposed dynamics. This follows from the way in which economic nationalism is traditionally identified with policies such as mercantilism, protectionism, tariffs, quotas and trade barriers (e.g. Gilpin 1987), or seen as an approach which competes with neoliberalism not only normatively but also ontologically (e.g. O'Brien and Williams 2004). As a result, economic nationalism is viewed as an anachronistic economic doctrine in an 
age of intensifying transnational practices, world-wide dispersion of production powers and downsizing of the economic functions of the state. In a similar tone, discussions on economic nationalism in Russia commonly focus on issues such as restrictions to foreign participation within 'strategic sectors', the creation of 'national champions' or the activities of the 'Kremlin-supported oligarchs' (e.g. Goldman 2008: 98-99; Liuhto 2008).

Scholars pursuing the 'new research agenda on economic nationalism' have challenged the juxtaposition of economic nationalism and (neo)liberalism. This has involved sharpening and widening the concept of economic nationalism: the 'nationalist content' of economic nationalism has been resuscitated (Helleiner 2002) and the fact that 'nationalism as a generic phenomenon is ... compatible with a variety of ideological content' has been emphasised (Pickel 2005: 8; see also Crane 1998; Crane 1999). It has been pointed out that in many cases the discourse of nation has in fact played an important role in attempts to gain support for economic liberalism (e.g. Hall 2005; Müller 2005). Scholars have emphasised the fact hat economic nationalism as an analytical concept should be dissociated from specific economic policies (e.g. Goff 2005: 185).

The new research agenda examines economic nationalism as the economic facet of national identity (Crane 1999: 215) or places some other 'nationalising mechanism' at the centre of analyses: 'The emergence of a global financial system, for example, can and should be conceptualised as the result of particular nationalising policies of individual states - that is, the attempt to reposition 'their' economies in the global system' (Pickel 2003: 124, n. 16). It is presupposed that nationalism in one way or another causes, influences or shapes policies the ensemble of which is then defined as 'economic nationalism' (Helleiner 2002: 326). Economic nationalism, in the words of Rawi Abdelal, refers to 'a set of policies that result from a shared national identity, or from the 
predominance of a specific nationalism in the politics of a state' (Rawi Abdelal cit. Helleiner 2002: 310). This has commonly involved subsuming economic nationalism under the 'nationalising mechanism' (Pickel 2003: 118) or working on the basis of 'nationalist ontology' (Helleiner 2002). In terms of a research design, this means first identifying nationalists and then moving on to examine their policy preferences in the realm of international economic integration (Shulman 2000: 368). Nationalists are defined as those people who pursue nationalist goals such as 'the unity, identity, and autonomy of a nation or potential nation' and demonstrate 'great pride in the culture, territory, history, and destiny of a nation' (Shulman 2000: 368). These goals, the argument goes, may sometimes be best served by liberal or neoliberal policies.

I share the new research agenda's concern to revisit the relationship between economic nationalism and neoliberalism but instead of working on the basis of any nationalist ontology, I hypothesise that the discourse of nation may in fact significantly contribute toward the expansion of the market civilisation which is framed by the discourse of globalising neoliberalism (Gill 1995: 399). In many ways, such a possibility is actually embedded in the argumentation of the above-mentioned scholars: '[n]ationalists are not uniformly against close international ties [which] raises the intriguing possibility that economic integration and globalisation have proceeded so swiftly not despite nationalism, but in part because of it' (Shulman 2000: 368; see also Helleiner 2002: 326).

This article thus emphasises the role of the discourse of nation in the expansion of the neoliberal market civilisation. It argues that the nation remains a powerful repertoire of meanings that is, among other things, drawn upon to construct interpretations of policies that resonate with the neoliberal political rationality. On the empirical level, the focus of the article is not on the economic policies of 'nationalists' or 'neoliberals'. Thus, I am not 
arguing that the mobilisation of the discourse of nation is purely instrumental or politically expedient. Rather, the article scrutinises the ways in which the discourse of nation interacts and plays together with the global standards of market civilisation in the Russian context. The approach taken resonates with ideas that have been put forward in recent scholarly literature on nationalism; these studies have argued that the nation is a symbolic system that can be actualised through political action in different ways depending on the specific historical context (e.g. Brubaker \& Cooper 2000; Calhoun 1997; Verdery 1996). In a similar vein, this article suggests that the discourse of nation is strategically mobile. This renders it genuinely compatible with different governmental logics, including the neoliberal logic of the expanding market civilisation.

\section{Neoliberal market civilisation}

After the dissolution of the USSR in 1991, Russia has explicitly adopted the objective of moving towards a market economy. This article turns to the notion of market civilisation to conceptualise such movement. The academic discussion on market civilisations has been inspired by debates on the historical expansion of international society (for a slightly different approach, see Gill 1995). The notion of international society is used to refer to a situation where there are some fundamental commonalities - shared interests and values, commonly binding rules and common institutions - among states. International society is qualitatively different from an international system where 'two or more states have ... sufficient impact on one another's decisions ... to make the behaviour of each a necessary element in the calculations of the other' (Bull 1995).

In the context of international societies, the standard of civilisation has historically functioned as 'an expression of the assumptions, tacit and explicit, used to distinguish 
those that belong to a particular society from those that do not' (Gong 1998). I suggest that the standard of civilisation can be conceptualised as a form of productive power, a dominant discursive structure which ensures conformity by providing a set of norms against which agents evaluate and discipline not only others but also themselves (cf. Manokha 2009). By 1905, at the latest, a specific standard of civilisation had emerged as a central tenet of international law. It codified the criteria used to distinguish between 'civilised' and 'uncivilised' peoples and to determine membership in the 'family of nations' (Gong 1998). This $19^{\text {th }}$ century standard of civilisation was primarily a legal mechanism that established the boundaries of the privileged group able to enjoy the advantages of international law: full sovereignty, full recognition, and protection under international law (Best 2006: 135; Bowden and Seabrooke 2006: 6).

Discussions on contemporary international society as a market civilisation suggest that after the legal standard of civilisation was abandoned at the close of the Second World War, states have been increasingly judged - and have been judging themselves - against the benchmarks set by the discourse of globalising neoliberalism (Gill 1995: 399). This discourse centres on market liberalism and the imperatives of capital accumulation, i.e. global dispersion of productive processes, the expansion of financial capital and state transformation in terms of economisation, privatisation and downsizing of the state's key economic functions. As a form of productive power it is geared at improving conditions for economic interaction on the global scale (Bowden 2006: 30).

The rise in importance of the primary institution of the market is also exemplified by the emergence of a new set of benchmarks that Gong designates as the 'standard of financial modernity' (Gong 1998). Instead of seeking affirmation of their sovereignty from other states, states now seek recognition primarily as full members of the modern financial and 
trading system (e.g. Putin 2012). A concrete manifestation of the workings of contemporary, market-oriented global standards is seen in more or less explicit hierarchies of different peoples and states; if the $19^{\text {th }}$ century standard of civilisation drew distinctions between 'civilised' and 'uncivilised' states, contemporary standards distinguish between 'developed economies', 'emerging economies', and 'non-market economies' (Bowden 2006: 31; Gong 1998).

Thus, instead of working on the basis of a nationalist ontology, my analysis is based on the idea that contemporary international society is a neoliberal market civilisation and that states seeking to be recognised as its full members are being judged against a set of neoliberal standards. Arguably, the contemporary Russian modernisation project may be examined as an illustration of the significance of such standards. To briefly illustrate, former president Dmitri Medvedev argued that the modernisation of Russia is necessitated by the fact that the country is not fully 'comparable to other rapidly developing nations' (Medvedev 2010). The Skolkovo innograd is also represented as a step to this direction; in the occasion of initiating the project, Medvedev argued that improving the standing of Russia among global powers requires the building of a 'world-class research and development centre comparable to the American Silicon Valley' (Medvedev 2009). However, it would be erroneous to interpret such practices as a simple outcome of the increasing power of neoliberal standards. It makes more sense to examine the Russian modernisation project as a field of tensions that escapes easy classifications. My argument is that the discourse of nation provides a set of historically rooted ideas that can be actualised to draw meaningful interpretations - supportive as well as critical - of a project that can be seen as embedded in the contemporary market civilisation.

\section{The Skolkovo innograd and market civilisation}


The on-going construction of the Skolkovo innovation city provides a fruitful opportunity to examine how the discourse of nation interacts and plays together with the global standards of market civilisation. At issue in the Skolkovo project initiated in 2009 is the construction of a 'Russian Silicon Valley' expected to diversify the country's economy away from oil and gas. Skolkovo is envisaged to provide the infrastructure and favourable economic conditions for companies working within the five priority sectors of biomedical technologies, energy efficiency, information and computer technology, space technology, and nuclear technology. The Federal Law on Skolkovo Innovation Center was adopted in 2010; the first buildings will be built in 2012 and, according to the plan, the centre's main facilities will be completed by 2015 . The completed innograd is expected to span roughly 400 hectares and offer work for 30 thousand people. A special Fund for the Development of the Centre for Elaboration and Commercialisation of New Technologies (i.e. Skolkovo Foundation) has been set up to manage the project and oversee the construction of the town. The Foundation is headed by the businessman Viktor Vekselberg, but it functions in close cooperation with the Russian government. The volume of state budget funding for the innovation centre between 2010 and 2015 is approximately 85 billion Russian rubles (2,3 billion euros) (e.g. Minfin 2011).

This article conceptualises the Skolkovo project as an example of the way in which the standards of market civilisation are taken into use in Russia. There is much to the project to suggest that it forms part of the process whereby the discourse of globalising neoliberalism - 'an ethos that would permit no barrier to market forces' (Ong 2003: 153) spreads across the world. Firstly, it is underpinned by a script whereby the 'world economy' is being transformed into a 'global economy' dominated by transnational economic actors. Secondly, the debate on Skolkovo revolves around the standard of 
market civilisation as polemicists represent the innograd as a means to increase Russia's attractiveness in the eyes of globally 'footloose' capital, companies, and talent. Thirdly, human individuals are conceptualised first and foremost in terms of homo oeconomicus, a figure evaluated on the basis of his or her ability to invert human capital into income stream.

The argument of this article is that although the debate on Skolkovo clearly resonates with the neoliberal standards of market civilisation, it would be erroneous to overlook the elements of economic nationalism within it. It is worth analysing how the standards of market civilisation and the discourse of nation are productively intertwined in the discussion over the project. Instead of evaluating whether Skolkovo actually enables Russia to measure up to the standards of market civilisation, the focus of this article is on the arguments that such ambitions animate and on the kinds of policies that are subsequently adopted. The research materials have been collected from the websites of relevant governmental authorities and the Integrum database complemented by the author's daily perusal of the Russian press. The materials used thus include statements on Skolkovo by supporters and critics alike. Skolkovo is a state project but those speaking in favour of it include not just top officials but also a number of key leaders in business and science. Criticism is heard from representatives of the domestic opposition as well as nonpartisan commentators on domestic affairs.

\section{Analysis: the discourse of nation and the Skolkovo debate}

This section first discusses how the innograd project makes sense in the context of the neoliberal market civilisation that comprises contemporary international society. It then moves on to illustrate four ways in which the discourse of nation is mobilised both by 
supporters and critics alike to argue meaningful interpretations of the project. The discourse of nation nationalises the project by placing it within the context of a national social purpose. It naturalises the project by suggesting that engagement with the types of activities that rank high in the standards of market civilisation is only natural for Russia and Russians. It idealises the project by linking it to a compelling view of the future and investing it with emotions of national pride and importance. All these framings serve to depoliticise the project, to place it outside of present day political debates as well as to encourage the logic of neoliberal competition within other sectors while protecting the political status quo. (Cf. Fougner 2006.)

\section{Neoliberal Skolkovo}

An indicator of the standards of market civilisation motivating the contemporary Russian modernisation project and Skolkovo as a part of it is its spatial imaginary. Instead of enforcing the idea of the territorial integrity of the Russian nation, the polemicists often rely on the spatial imaginary of the 'nodal landscape' which is inspired by the neoliberal paradigm (e.g. Desrosières 2003: 563). The Skolkovo project does not turn on the familiar Westphalian image of the global political space divided into sovereign nation-states. Instead, it is underpinned by the idea of a 'common technological and innovative space' (Medvedev 2011) which resonates with neoliberal visions of an emerging borderless world (e.g. Ohmae 1996). A small number of places on a sub-national scale that are (or have the potential to become) key nodes in the networks of world economy are emphasised. Skolkovo's spatial imaginary thus signals a departure from the familiar structure of the nationally-scaled image of Russian/Soviet space hierarchically organised around a dominant centre (Moscow) with radiant lines of influence extending over the rest of the state territory (French 1984: 362). Neither does it resonate with the imperial vision and its 
'massive aesthetic of whole continents and peoples and Russia's power and influence within that global scenario' (Clowes 2011: 49). Rather, the innograd is envisaged as a key node in a global network of significant places.

This conceptualisation is tied to a specific understanding of the character of contemporary global politics. Flexible accumulation and the connected idea of spatial deconcentration are assumed to go hand-in-hand with a reconcentration of finance and management in certain hotspots. Nation-states are thus replaced as the key organising spatial nodes of a new global economic system' and the hot-spots 'bypassing' their nation-states are assumed to form separate supranational networks among themselves (Golubchikov 2010: $626)$.

The nodal spatial imaginary gains backing from an assumption of the mobility of a specific group of people: professional cosmopolitan migrants who the market civilisation privileges (Ong 2003:154). Skolkovo is designed namely for such an elite. Its city manager argues that for great many Skolkovo residents the proximity and ease of access to the international airport will be of much more importance than local automotive or train connections (Viktor Maslakov cit. Kommersant 2011). As an outright renunciation of the national discourse, Skolkovo is thus advertised as a non-Russian location, a place where the global elite can feel at home. Echoing Gerrit Gong's notion of 'cosmopolitan culture' as the emerging global standard of civilisation (Gong 1984: 92), the character of the innograd as a 'multi-cultural city' is highlighted; 'we want the culture of every country to be represented here' (Viktor Maslakov cit. RIA Novosti 2011). Although Russia is a multiethnic state, here ethnicity obviously figures differently, as an element of the cosmopolitan discourse (cf. Ong 2003: 154). 
Aihwa Ong has scrutinised the ways in which the neoliberal script of globalisation has given rise to 'new spaces' in South East Asia, spaces defined by different rationalities than the rest of the state territory (Ong 2004). Quite similarly, the Skolkovo plan relies on a number of procedures, instruments and tactics that enforce the logic of neoliberal exceptions over Russia's state space. At issue here is the 'insertion of optimising calculations or tactics in some domains but not in others' (Ong 2008: 121) - or over parts of the population but not over others. Skolkovo is a unique domain within Russia's state space and its uniqueness is a result of a cascade of interventions that either privilege or disadvantage specific groups of people depending on their capacity to engage global market interests. In this sense, the Skolkovo project might be argued to follow the logic of the global standard of market civilisation and its neoliberal ethos rather than the logic of the discourse of nation.

The exceptional character of the Skolkovo innograd as a 'geographically separate complex' is explicitly affirmed in the law (Federal Law 2010). The law exempts participants to the Skolkovo project from various legal norms and regulations in the fields of customs, taxation, immigration and administration (Federal Law 2010; Federal Law 2011). These are concrete examples of the workings of a standard of civilisation geared at creating optimal conditions for economic interaction. The rhetoric of Skolkovo further detaches it from the rest of the national territory by invoking such standards of financial modernity as absence of corruption, protection of investor rights and property as well as transparent judicial and administrative processes. The innograd is thus represented as immune to problems that are commonly perceived to hamper foreign investment inflows to Russia (Vedomosti 2010b). 
Another illustration of the downplaying of the scale of the nation is the fact that the dynamics of inclusion and exclusion are not dependent on one's citizenship. Rather, they follow from an individual's value as determined by global market standards. Skolkovo is exclusionary with regard to Russian citizens and foreigners who are not capable of engaging global market interests and inclusionary with regard to those Russians and foreigners who are. In the logic of Skolkovo, people figure as 'differentially capitalised citizen-subjects' (Ong 2003: 163). A set of procedures which makes the entry into the Russian Federation significantly easier for qualified foreign specialists who work in Skolkovo has been introduced to the law (Federal Law 2011; see also Interfax 2010). Another example of the logic that empowers market forces vis-à-vis the original population is an interview with the city manager of the innograd; it reveals a worry that the surrounding population whose social and cultural background differs from the inhabitants of Skolkovo might 'flood' into the innograd to benefit from its services. Curiously, however, the decision not to prevent the original population from entering Skolkovo hinges on the neoliberal logic of innovations requiring openness (Viktor Maslakov cit. Kommersant 2011).

The new legislation also regulates the right to gain residence in Skolkovo. All property is owned by the management company and project participants will be able to rent it and provide housing for their employees (Federal Law 2010). Renting out is expected to promote the mobility and flexibility which is central to the constitution of flexible transnational economies; once tasks have been accomplished, people are welcome to leave. The city manager of Skolkovo envisages the place as a 'town of temporary population' and uses the Soviet experience as a negative example: the city will not repeat the mistake of the closed cities of science that became permanent places of residence for ageing and 'inert' scientists (Kommersant 2011). The entitlement to reside in a certain 
territory is here used as an instrument with the help of which capital and commercial flows are facilitated (Rose 1999: 481).

\section{Nationalisation}

Although the Skolkovo project is in many ways premised on a set of neoliberal ideas that envisage an unlimited global market and a borderless world (e.g. Medvedev 2011), the mobilisation of the discourse of nation in debates on the innograd simultaneously serves to reproduce the image of Russia as a nation and a sovereign state.

The construction of the Skolkovo innograd is motivated by the idea of Russia lagging behind in international competitiveness (e.g. Skolkovo Foundation 2010). International competitiveness is one of the benchmarks imposed by contemporary market civilisation, but it also has curious potential to turn issues into questions of national importance. Firstly, envisaging Russia as one among several nations engaged in economic competition reproduces the image of the world that consists of nations and their relations (cf. Fougner 2006: 183). Secondly, international competitiveness often comes to mean interjurisdictional competition and the desire to 'lock in' the benefits of free market policies may actually motivate regulatory sovereignty in the context of international capital mobility (Harmes 2012).

Within the Skolkovo debate the notion of international competitiveness is actualised in a form which reproduces the myth of the nation's citizenry sharing a common economic fate. In fact, the argumentation of supporters and critics alike revolves around this myth. While supporters mobilise it to suggest that the well-being of each and all depends on the achievement of the benchmarks that the Skolkovo plans set, critics point out that the 
suggested policies are likely to have an uneven impact on Russians across gender, class and location. They argue that the chosen policy disadvantages Russians at the expense of foreigners or simply benefits those Russians who are already well-off.

Critics of the project thus activate the idea of the primacy of the nation as they characterise Skolkovo as a zone into which certain foreigners - individuals and businesses - are being attracted but from which Russian citizens or institutions are not able to benefit. In a caricature published in the Vedomosti newspaper, the head of the Skolkovo project Viktor Vekselberg is depicted guarding the gates of the innograd from the representatives of the Federal Taxation Service as if he was St. Peter at the gates of heaven (Vedomosti 2010a). This constitutes an argument that instead of the Russian state and nation benefitting from the project, its tax incentives provide paradise-like conditions for foreigners to enjoy.

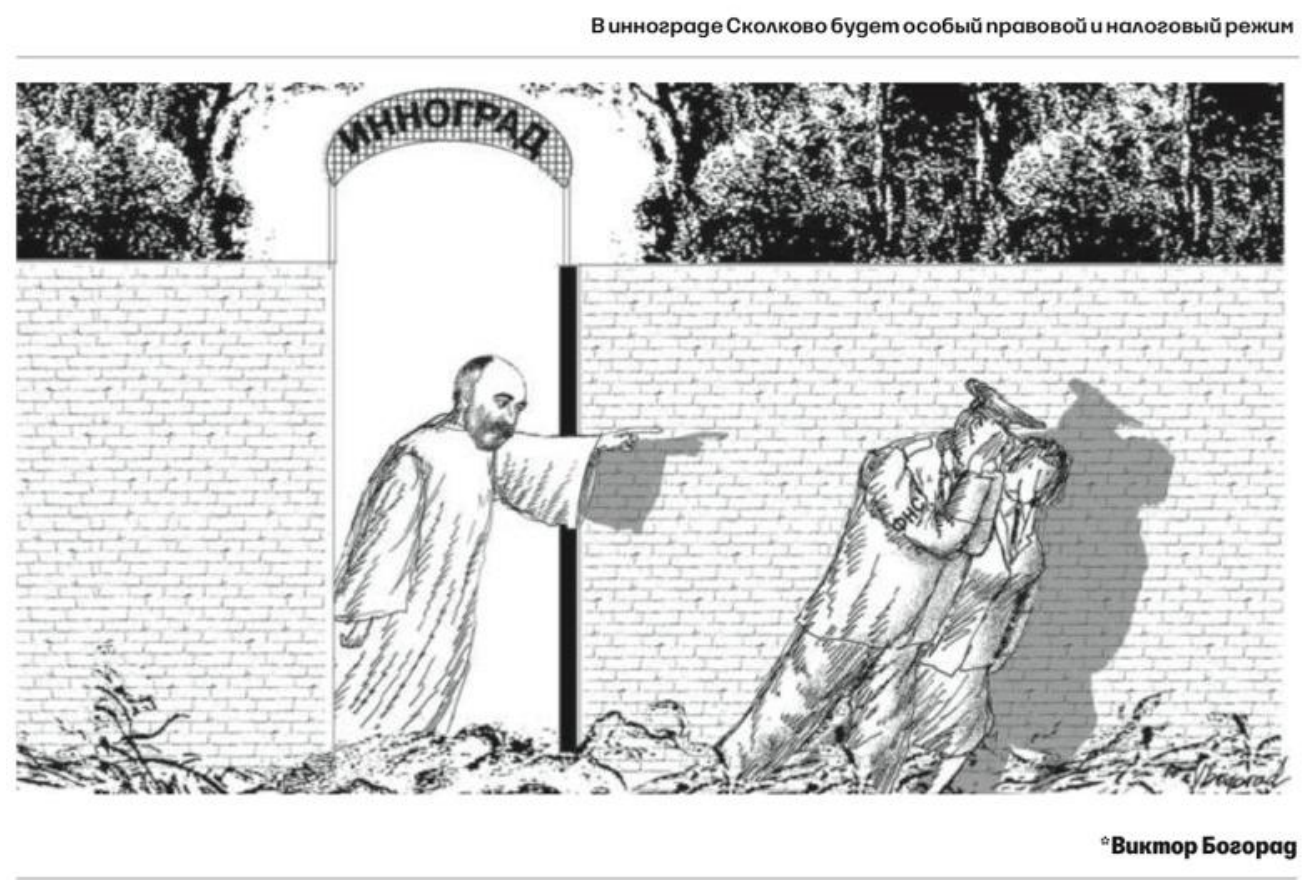

Similarly, the idea of a globally available workforce has been taken up to argue that the innograd is an arrangement which enables Western multinationals to exploit the Russian talent pool. Foreign corporations are argued to be interested in participating in the project 
mainly for the reason that the wages of Russian experts are lower than in many countries with an equally skilled labour force (e.g. Novaia Gazeta 2010). However, responding to such accusations, the representatives of the project also revert to the nationalising capacity of the discourse of nation. This is done with the help of what Billig (1995) has called the 'deixis of homeland', i.e. little words that invoke the national 'we' and imply that the discussed project relates to 'us' and address the audience as a nation (Billig 1995: 11, 108): 'it is particularly important that our foreign partners understand that they do not come to Skolkovo for huge profits or ... to take advantage of Russian talents. But [... in order to] to develop science, technology and innovations of our country together with us' (Alferov 2011). Such use of the deixis of homeland forms part of an attempt to persuade the audience that their interests are 'identical' with one another, and at the same time different from those of 'our foreign partners' (cf. Brubaker \& Cooper 2000: 4-5; see also Richter 1996: 70). In a similar tone, the recruitment of foreign experts is characterised as a 'pure necessity ... for Russia's modernisation to succeed' (Representative of Ministry of Economy cit. Vedomosti 2010d) or, alternatively, the 'patriotic' character of attempts to attract foreigners to work in Skolkovo is emphasised (Vladislav Surkov cit. Vesti24 2010b).

Large sums of public money are being invested in Skolkovo. But the innograd has been accused of being an oligarchic project and a smoke screen that the elite - 'politicians and closely affiliated oligarchs' - uses for private profit-making (Bazhanov 2010; Gennadii Ziuganov cit. Kommersant FM 2011; Nemtsov \& Milov 2010: 43; Novaia Gazeta 2010). The fact that the price of land is among the highest in the country is argued to raise doubts about the ability of ordinary engineers and small businesses to benefit from the Skolkovo project (Nemtsov \& Milov 2010: 43). From the perspective of the interplay of neoliberal standards and the discourse of nation it is quite interesting to note that the notion of oligarchy calls to mind the idea of a privileged group, and criticism of Skolkovo as an 
oligarchic project thus reverberates with the neoliberal demand for genuine competition. Here, the idea of Skolkovo as a violation of the norms of genuine competition is argued to render it incompatible with the interests of the Russian nation. The observation here is not simply that Skolkovo critics mobilise the discourse of nation against a neoliberal project but that these discursive structures intersect in the argumentation of both critics and supporters.

Idealisation

The way in which the discourse of nation is mobilised in debates over the Skolkovo innograd also serves to constitute specific types of business activities - those that reverberate with the main ideas of neoliberal market civilisation - as desirable and commendable, that is, to idealise them (see also Fougner 2006).

Skolkovo forms part of the contemporary project to modernise Russia in terms of expanding the high technology sectors in the country's economy. The project is underpinned by a somewhat pessimistic picture of the present state of the country's economy which is heavily dependent on raw materials' exports. This perpetuates the familiar image of Russia as a nation continuously catching-up with the 'West' (e.g. Gerschenkron 1962). Against this background, the 'theory' of (Porterian) clusters is taken up to offer a compelling view of the future. It is intertwined with the discourse of nation in suggestions that Russia has real potential to 'catch and overtake' other countries if it invests in selected clusters: information technology, biomedicine, energy efficiency, space, and nuclear technology (Skolkovo Foundation 2011a; see also Rossiiskaia Gazeta 2012). 
Although the discourse of nation plays an important role in interpretations of Skolkovo as a step toward a brighter economic future, the spatial logic of clusters is not nationally-scaled. It rather resonates with the above-discussed nodal imaginary of the global landscape (e.g. Porter 2008: 199). The assumption is that clustering on subnational scale enables local industry to become significant on the global scale, i.e. to 'compete globally' (Sum 2008: 143). Porterian cluster thinking is typically liberal (e.g. Fougner 2006) or neoliberal (e.g. Moisio 2008; Sum 2008). First, it invites governments to think of themselves as business environments, which illustrates the rise in importance of the primary institution of the market and the related expansion of business logic to sectors that previously have been relatively immune to its dictates. Second, it is strongly informed by the globalist conception of world economy; the scale of the nation is relatively irrelevant in efforts to foster 'truly global industries', i.e. such business endeavours that can succeed in global competition (Fougner 2006: 198). Third, the approach is motivated by the neoliberal impulse to economise on the use of resources and effort as illustrated by a pro-Skolkovo argument according to which 'for research activity to be efficient ... people must be together. Not three in Tomsk, three in Novosibirsk and four in Moscow' (Vladislav Surkov cit. Izvestiia 2010).

Such thinking clearly challenges the traditional view of Russia's vast territorial size and (relatively) even development across its territory as a guarantee of the country's high rank in the hierarchy of states. However, the discourse of nation plays an important role in efforts to come up with meaningful interpretations of this 'glocalising' process which, instead of being geared at equalising the distribution of population, industry and infrastructure across the national territory, is aimed at concentrating the capacities for economic development within clusters located at strategic subnational sites (cf. Brenner 2003). Here, the discourse of the nation invests the suggested policies with emotions of 
pride and anxieties which are linked to questions of Russia catching-up as well as fears about its sheer survival (cf. Sum 2008: 139). Skolkovo is promoted as a means that enables people to change their perception of Russia, to stop approaching it as an 'oil barrel' or a 'lump of firewood' and national prestige is interpreted in terms of ability to produce the most advanced technology (Vladislav Surkov cit. Vesti24 2010a). Arguably, this links issues of prestige to the idea of 'knowledge as capital' and, through it, to the neoliberal paradigm of market civilisation (e.g. Olssen \& Peters 2005: 330).

One outcome of the coarticulation of the discourses of nation and neoliberal market civilisation is that questions of image and reputation are thought of as an essential part of the nation-state's competitive advantage: 'countries represent themselves to global consumers and investors, acting like contestants [in] a beauty contest' (True 2005: 205). Often the proverbial beauty of states is measured by different neoliberally-structured ratings, such as corruption or competitiveness indices. Countries are first hierarchised in terms of their ability to appeal to globally footloose capital and differently-ranked countries are then invited to adopt certain market-friendly steps to increase their appeal and improve their position in the hierarchy. This is also an important element in the promotion of Skolkovo to foreign audiences (e.g. Russia Today 2010). The fact that such transnational mechanisms of surveillance and visibility figure as authoritative sources in discussions over the Russian innograd may be taken as one concrete example of the power of the standards of market civilisation over Russian authorities and - through their governmental interventions - over wider populations (cf. Fougner 2008: 318; Sum 2008). Importantly, however, the fact that Russia's position in various rankings is interpreted as a matter of national prestige provides one illustration of a productive relationship between the discourse of nation and the neoliberal market civilisation. 


\section{Naturalisation}

By 'naturalisation' I refer to the capacity of the discourse of nation to constitute the types of business activities that form part of the Skolkovo project as natural for Russia and Russians to invest and engage in (cf. Fougner 2006: 190). Although Skolkovo is a part of the Russian government's economic modernisation program, a set of non-economic meanings ascribed to the innograd serve to place the project within a wider frame than economy. In the context of the presentation of the nuclear cluster, for example, the Soviet atomic project is called to mind to imply that the decades-long experience with nuclear technology, beginning with the establishment of a nuclear laboratory at the Academy of Sciences in 1921, has placed the country in a 'unique position of global technological leadership' (Skolkovo Foundation 2011b). In the spirit of 'country branding', the polemicists rely on the discourse of nation as they emphasise and reinforce the distinctiveness of Russia and play up the uniqueness of the local population (see also True 2005: 202). Russia's reputation as the successor state of the first country to put a man in space and develop nuclear weapons as well as the home to many world-class physicists and engineers is frequently stressed (e.g. Skolkovo Foundation 2012: 3).

It is noteworthy that Russia's past is employed in the analysed materials in a form which is not in conflict with the standards of contemporary market civilisation. This is illustrated, for instance, in the discussion between supporters of the Skolkovo project and those speaking in favour of rather investing in the Soviet-era naukograds (cities of science) (e.g. Rosbalt 2011; cf. Alferov 2011). This discussion resonates with an increasingly pervasive neoliberal urban development script which suggests that with the dawn of a new form of capitalism based on human creativity 'effective people climates' which attract and retain particular types of people are becoming more important than business climates as such 
(Florida 2002; see also Peck 2005). In a similar tone, the character of the innograd as a 'cool', multicultural place is said to distinguish it from the naukograds of the Soviet era.

A completely new urban environment is argued to be needed in order to stimulate creativity in science and in business, to generate new forms of sociality and, ultimately, a new type of subject: a creative person blossoming with unforeseen commercial innovations (RIA Novosti 2011; Skolkovo Foundation 2011c). In the words of architect David Adjaye, the physical set-up of the Skolkovo School of Management is expected to encourage 'networking, cross-pollination and dialogue', i.e. qualities required from Moscow's new managerial class (Financial Times 2010). Although such characterisations of the new subject in many ways resemble the neoliberal homo oeconomicus, the historically-rooted discourse of nation plays an important role here (see also Salmenniemi 2012). In changing people, the architecture of the building appeals to Russian traditions as many of its architectural features call to mind the work of Kazimir Malevich and other Russian Suprematists. Curiously, the production of this artistic group was motivated by the idea of the past system as a defunct one. In the context of Skolkovo, the future is imagined with reference to the logic of expansive capitalism as illustrated by the School's mission to train leaders to the BRICs and other emerging markets which offer new possibilities for profit-making (e.g. Moscow School of Management 2011). Such selective use of Russian and Soviet histories illustrates that accommodation to the standards of an expanding market civilisation simultaneously invites the nation-state to play up its 'distinctive history, geography, and gender and ethnicity and in so doing (re)invent a sense of national identity in order to carve out a strategic niche and competitive advantage in the global economy' (True 2005: 204). 
One way in which the discourse of nation contributes to Russia's adaptation to the neoliberal market civilisation is that it is actualised, on the one hand, in attempts to place the Skolkovo project outside of present day political debates and, on the other hand, in efforts to dismiss the importance of competition within the country's political sector simultaneously with promoting open competition within business.

The previous sections have shown that the attempts to meet the standard of contemporary market civilisation partly rely on the idea of the innograd as a non-Russian location. The separation from the rest of Russian territory takes place not only with the help of rhetoric but also through a number of 'neoliberal exceptions' which are enforced with the help of legislation, taxation and architecture. Such neoliberal exceptions, however, coexist with 'exceptions to neoliberalism' which rule certain sectors, people, or places out from neoliberal calculations (Ong 2006: 4). In the case of Skolkovo, the political and business sectors are treated quite differently. A newspaper editorial argues that Skolkovo shows that the choice has been made to 'trade nanofilters' instead of encouraging institutional changes that would lead to the emergence of 'real competition in the economy and politics' (Vedomosti 2010c). In counterarguments, the discourse of nation is mobilised to dispute the importance of the modernisation of the country's political system. Russia's modernisation is said to follow a unique path of development due to which foreign models (e.g. 'Western democracy') cannot be simply replicated in Russia (e.g. Mau 2010: 100). Russia's uniqueness grounds an argument that although self-enterprising ethos and entrepreneurialism are needed in business, this is not necessarily the case within the political sector (cf. Ong 2008: 121). 
As Skolkovo is clearly a state project, critics quite often harness neoliberal demands to limit the functions of the state. 'Neo-liberalism', as Rose and Miler note, 'reactivates liberal principles: scepticism over the capacities of political authorities to govern everything for the best; vigilance over the attempts of political authorities to seek to govern' (Rose \& Miller 2010: 296). In many instances, the polemicists play on the neoliberal suspicion of the state not only governing too much but intervening in the sector of innovations where its involvement is actually harmful: state servants are not the right figures for the task of constructing an innovation economy and the mediocrity of bureaucrats is contrasted with the inventiveness of entrepreneurs (Igor' Nikolaev cit. Finam FM 2010; Nikishenkov 2011). Here, the discourse of nation and the trope of its uniqueness are taken up by the supporters to defend the central role of the state and its head. The presidential character of the Skolkovo project is legitimised by arguing that in order for anything substantive to work in Russia, the head of state has to be involved (Dmitri Medvedev cit. Reuters 2010). The discourse of nation thus serves to defend the role of the state within a project whose

ethos is in many ways neoliberal. Arguably, such a combination of elements is expected to enable Russia to take part in neoliberal competition for footloose capital without jeopardising the system of 'sovereign democracy' (see also Mäkinen 2011).

\section{Conclusions}

Arguably, one of the paradoxes of our time is that states promote denationalising and transnationalising policies in order to deal with national problems, in the name of their 'national interest' (Beck 2005). This apparent paradox lies at the heart of this article. This 
paper is a contribution to the recent efforts to redefine economic nationalism and to challenge the conventional view which associates it with illiberal or statist policies or characterises it as an approach competing with neoliberalism not only normatively but also ontologically. Building on the work of scholars representing the "new research agenda of economic nationalism', I have sought to argue that there is no inherent contradiction between economic nationalism and neoliberalism. But instead of working on the basis of any 'nationalist ontology' as the representatives of this new research agenda do, I have attempted to develop my argument in the context of the idea of contemporary international society as a market civilisation where states are increasingly evaluated against - and where they evaluate themselves - against neoliberal standards of civilisation. I have argued that the discourse of nation provides an important repertoire of meanings that is being drawn upon to argue meaningful interpretations of policies that reverberate with the standards of neoliberal market civilisation.

With this as my point of departure, I have argued that the contemporary modernisation project of the Russian state constitutes a field of tensions and that the political dynamics at play within it thus escape simple classifications. More specifically, I have focused on how the discourse of nation and neoliberal standards function hand-in-hand within domestic debates over a flagship project of the modernisation project, the construction of a technocitadel in Skolkovo in the outskirts of Moscow. This has involved highlighting how these discursive structures at times challenge and at other times find support from one another.

In particular, I have argued that the discourse of nation helps to nationalise, naturalise, idealise and depoliticise a project which resonates with the neoliberal ethos of contemporary market civilisation which would permit no barrier to market forces. Although the Skolkovo project is in many ways underpinned by the neoliberal idea of a "borderless 
world' rather than the modern image of the global space divided into separate nationstates, the discourse of nation nationalises the project, that is, constitutes it as a matter of national importance. The discourse of nation also contributes toward depoliticising the Skolkovo project by attempting to place it outside of present day political debates as well as silencing arguments that highlight the importance of increasing open competition not only within business but also within the political sector. Under the discussion on idealisation I have illuminated how the discourse of nation invests the innograd with emotions of pride and anxiety and links it to the thematic of a brighter future for Russia. The capacity of the discourse of nation to naturalise a set of policies attuned to the dictates of contemporary market civilisation refers to the representation of the Skolkovo project and the types of activities associated with it as somehow natural for Russia and Russians to invest in. This involves highlighting continuity with the country's historical past as well as emphasising the distinctiveness of the country and its inhabitants in a way that is expected to reverberate with the standards of market civilisation.

The empirical case under study here thus provides support for the invitation to revisit the conventional usage which juxtaposes economic nationalism to liberal or neoliberal economic policies and sees them as mutually exclusive. Firstly, the an interplay between the discourse of nation and the neoliberal discourse of market civilisation can often be found - their relationship is productive rather antithetical. Secondly, globalising and nationalising processes commonly interact, which may be taken to suggest that despite its characteristic vision of an emerging borderless world, neoliberal globalisation actually requires nationalising processes to become effective. 


\section{References}

Alferov, Z. 2011. 'Talanty dlia novoi Rossii: myslit' "po-Skolkovski”', Saint-Petersburg Economic Forum, 16-18 June 2011.

Bazhanov, Yevgeny 2011. 'Overcoming the bazaar mentality', Moscow Times, opinion 17 March 2011.

Beck, U. 2005. 'The cosmopolitan state: redefining power in the global age', International Journal of Politics, Culture, and Society 18, 3-4: 143-159.

Best, J. 2006. 'Civilising through transparency: The International Monetary Fund' in B. Bowden and L. Seabrooke (eds.), Global Standards of Market Civilisation. Abingdon: Routledge.

Billig, M. 1995. Banal Nationalism. London: Sage.

Bowden, B. 2006. 'Civilization, standards, and markets', in B. Bowden and L. Seabrooke, (eds.) Global Standards of Market Civilization. Abingdon: Routledge.

Bowden, B. and Seabrooke, L. 2006. 'Civilizing through global standards', In B. Bowden and L. Seabrooke, (eds.) Global Standards of Market Civilization. Abingdon: Routledge.

Brenner, N. 2003. "Glocalization' as a state spatial strategy', in J. Peck and H. Yeung, (eds.), Remaking the Global Economy: Economic-geographical Perspectives. London: Sage.

Brubaker, R. and Cooper, F. 2000. 'Beyond "identity"', Theory and Society, 29, 1:1-47.

Bull, H. 1995. The Anarchical Society. New York: Columbia University Press. 
Calhoun, C.J. 1997. Nationalism. Minneapolis: University of Minnesota Press.

Clowes, E. 2011. Russia on the Edge: Imagined Geographies and Post-Soviet Identity. Itacha: Cornell University Press.

Crane, G.T. 1998. 'Economic nationalism: bringing the nation back in', Millennium: Journal of International Studies, 27, 1: 55-75.

Crane, G.T. 1999. 'Imagining the economic nation: globalisation in China', New Political Economy, 4, 2: 215-232.

Desrosières, A. 2003. 'Managing the economy', in R. Porter, T. M. Porter and D. Ross (eds.), The Cambridge History of Science: The Modern Social Sciences. Cambridge University Press.

Federal Law 2010. 'Federal'nyi zakon N 244-FZ 'Ob innovatsionnom tsentre 'Skolkovo", 28 September 2010.

Federal Law 2011. 'Federal'nyi zakon N 42-FZ ‘O vnesenii izmenenii v Federal'nyi zakon 'O migratsionnom uchete inostrannykh grazhdan $\mathrm{i}$ lits bez grazhdanstva $v$ Rossiiskoi Federatsii' i otdel'nye zakonodatel'nye akty Rossiiskoi Federatsii', 20 March 2011.

Finam FM 2010. Skolkovo - "sharashkina kontora" ili innovatsionnyi proryv? interview with Igor Nikolaev. Radio programme, 1 July 2010.

Financial Times 2010. 'Russian evolution at Skolkovo', 25 January 2010.

Florida, Richard 2002. 'The rise of the creative class', Washington Monthly, May 2002, available at http://www.washingtonmonthly.com/features/2001/0205.florida.html, accessed 5 May 2012. 
Fougner, T. 2006. 'Economic nationalism and maritime policy in Norway', Cooperation and Conflict, 41, 2: 177-201.

Fougner, T. 2008. 'Neoliberal governance of states: the role of competitiveness indexing and country benchmarking', Millennium: Journal of International Studies, 37, 2: 303-326.

French, R.A. 1984. 'Moscow the socialist metropolis' in A. Sutcliffe, ed. Metropolis 18901940. Chicago: University Of Chicago Press.

Gerschenkron, A. 1962. Economic Backwardness in Historical Perspective, Cambridge: Harvard University Press.

Gill, S. 1995. 'Globalisation, market civilization and disciplinary neoliberalism', Millennium: Journal of International Studies, 24, 3: 399-423.

Gilpin, R. 1987. The Political Economy of International Relations. Princeton: Princeton University Press.

Goff, M. 2005. 'It's got to be sheep's milk or nothing! Geography, identity, and economic nationalism', in E. Helleiner and A. Pickel (eds), Economic Nationalism in a Globalizing World. Ithaca: Cornell University Press.

Goldman, M.I. 2008. Petrostate: Putin, Power, and the New Russia. Oxford: Oxford University Press.

Golubchikov, O. 2010. 'World-city-entrepreneurialism: globalist imaginaries, neoliberal geographies, and the production of new St Petersburg', Environment and Planning A, 42, 3: 626-643. 
Gong, G.W. 1984. The Standard of Civilization in International Society. Oxford: Clarendon Press.

Gong, G.W. 1998. 'Asian financial crisis: culture and strategy,' Paper presented at ICAS Fall Symposium, University of Pennsylvania. Available at: http://www.icasinc.org/1998/1998f/1998fgwg.html [accessed February 13, 2012].

Hall, D. 2005. 'Japanese spirit, western economics: the continuing salience of economic nationalism in Japan', in E. Helleiner and A. Pickel (eds) Economic Nationalism in a Globalizing World. Ithaca: Cornell University Press.

Harmes, A. 2012. 'The Rise of Neoliberal Nationalism', Review of International Political Economy Review of International Political Economy, 19, 1: 59-86.

Helleiner, E. 2002. 'Economic nationalism as a challenge to economic liberalism? Lessons from the 19th Century', International Studies Quarterly, 46, 3: 307-329.

Interfax, 2010. 'Kremlin official wants more foreign experts in Russian science, business', 7 October 2010.

Izvestiia, 2010. 'Kriticheskaia massa intellekta', 8 October 2010.

Kommersant, 2011. "Skolkovo - gorod vremennogo naseleniia", Review Skolkovo, 15 November 2011.

Kommersant FM, 2011. "Davai seichas otremontiruem politicheskuiu sistemu, vperedi prezidentskie vybory", 22 December 2011.

Liuhto, K., 2008. 'Genesis of economic nationalism in Russia', Electronic Publications of Pan-European Institute, 3/2008. Available at: 
http://www.tse.fi/Fl/yksikot/erillislaitokset/pei/Documents/Julkaisut/Liuhto 32008.pdf [accessed 15 June 2012].

Manokha, I. 2009. 'Foucault's concept of power and the global discourse of human rights', Global Society 23, 4: 429-452.

Mau, V. 2010. 'The state and creation of a market economy in Russia', in I. Korhonen and L. Solanko (eds.), From Soviet Plans to Russian Reality. Helsinki: WSOY.

Medvedev, D. 2009. 'Poslanie Federal'nomu Sobraniiu Rossiiskoi Federatsii', 12 November 2009. Available at http://www.kremlin.ru/transcripts/5979 [accessed 1 December 2011].

Medvedev, D., 2010. 'Stenograficheskii otchet o vstreche s aktivom vserossiiskoi politicheskoi partii "Edinaia Rossiia", 28 May 2010. Available at: http://kremlin.ru/transcripts/7896 [accessed 1 December 2011].

Medvedev, D. 2011. 'Sovmestnoe zasedanie Komissii po modernizatsii i Popechitel'skogo soveta fonda "Skolkovo', 25 April 2011. Available at: http://kremlin.ru/transcripts/11079 [accessed 1 December 2011].

Minfin 2011. Osnovnye napravleniia biudzhetnoi politiki na 2012 god i planovyi period 2013 i 2014 godov. Available at: http://www.minfin.ru/common/img/uploaded/library/2011/07/ONBP 2012-2014.doc [accessed 4 May 2012].

Moisio, S., 2008. 'Towards attractive and cost-efficient state space: political geography of the production of state transformation in Finland', World Political Science Review, 4, 3: 1-34. 
Moscow School of Management 2011. High Five 2006-2011. Moscow: Moscow School of Management.

Müller, K., 2005. 'Nationalist undercurrents in German economic liberalism', in E. Helleiner and A. Pickel (eds) Economic Nationalism in a Globalizing World. Ithaca: Cornell University Press.

Mäkinen, S. 2011. 'Surkovian narrative on the future of Russia: making Russia a world leader', The Journal of Communist Studies and Transition Politics, 27, 2: pp.143165.

Nemtsov, B. and Milov, V., 2010. Putin. Itogi. 10 let, Moscow: Solidarnost'.

Nikishenkov, O. 2011. 'A Soviet Skolkovo', The Moscow News, blogs. Available at: http://themoscownews.com/blogs/20110415/188587716.html [accessed 22 February 2012].

Novaia Gazeta 2010. 'Budet Medvedevu nauka', 30 September 2010.

O'Brien, R. and Williams, M. 2004. Global Political Economy: Evolution and Dynamics. London: Palgrave.

Ohmae, K. 1996. The End of Nation-States: The Rise of Regional Economies, New York: Free Press Paperbacks.

Olssen, M. and Peters, M.A. 2005. 'Neoliberalism, higher education and the knowledge economy: from the free market to knowledge capitalism', Journal of Education Policy, 20, 3: 313-345. 
Ong, A. 2003. 'Techno-Migrants in the Network Economy', In U. Beck, N. Sznaider and R. Winter (eds). Global America? The Cultural Consequences of Globalization. Liverpool University Press, pp. 153-173.

Ong, A. 2004. 'Ecologies of expertise: assembling flows, managing citizenship', in S. J. Collier and A. Ong (eds.) Global Assemblages: Technology, Politics, and Ethics as Anthropological Problems. London: Wiley-Blackwell.

Ong, A. 2006. Neoliberalism as Exception: Mutations in Citizenship and Sovereignty, Durham: Duke University Press.

Ong, A. 2008. 'Scales of exception: Experiments with knowledge and sheer life in tropical Southeast Asia', Singapore Journal of Tropical Geography, 29, 2: 117-129.

Peck, J. 2005. 'Struggling with the creative class', International Journal of Urban and Regional Research, 29, 4: 740-770.

Pickel, A. 2003. 'Explaining, and explaining with, economic nationalism', Nations and Nationalism, 9: 1: 105-127.

Pickel, A. 2005. 'Introduction: false oppositions' in E. Helleiner and A. Pickel (eds.), Economic Nationalism in a Globalizing World. Itacha: Cornell University Press.

Porter, M.E. 2008. On Competition, Boston: Harvard Business Press.

Putin, V. 2012. 'Rossiia sosredotachivaetsia — vyzovy, na kotorye my dolzhny otvetit', Izvestiia, 16 January 2012.

Reuters 2010. 'Kremlin wins first deal for Russian Silicon Valley'. Available at: http://www.reuters.com/article/2010/05/28/russia-technologyidUSLDE64R1N620100528 [accessed 10 January 2012]. 
RIA Novosti 2011. 'Sozdateli Skolkovo obsudili zhil'e i kul'turu innovatsionnogo goroda', 1March 2011.

Richter, J. 1996. 'Russian foreign policy and the politics of national identity', in C. A. Wallander (ed.), The Sources Of Russian Foreign Policy After The Cold War. Boulder: Westview Press.

Rosbalt 2011. 'Sovetskie naukogrady nraviatsia Putinu bol'she, chem "Skolkovo"', 14 March 2011.

Rose, N. 1999. 'Inventiveness in politics', Economy and Society, 28, 3: 467-493.

Rose, N. and Miller P. 2010. 'Political power beyond the state: problematics of government', The British Journal of Sociology, 61: 271-303.

Rossiiskaia Gazeta 2012. 'Na iadernom "iakore": Minekonomrazvitiia gotovit novye programmy dlia monogorodov', 17 February 2012.

Russia Today 2010. 'Russian Silicon Valley to be corruption free', 30 April 2010, available at http://rt.com/business/news/russian-silicon-valley-corruption/ [accessed 10 October 2012].

Salmenniemi, S. 2012. 'Post-soviet khoziain: class, self and morality in Russian self-help literature', in S. Salmenniemi (ed.), Rethinking Class in Russia. Farnham: Ashgate.

Sharonov, A. 2012. 'Kak raskryt' preimushchestva Moskvy', opinion, 10 February 2012.

Shulman, S. 2000. 'Nationalist sources of international economic integration', International Studies Quarterly 44, 3: 365-390.

Skolkovo Foundation 2010. Mandat fonda "Skolkovo". Available at: http://www.sk.ru/ruRU/Model/Documents/MandatSkolkovo.aspx [accessed 1 April 2012]. 
Skolkovo Foundation 2011a. Klastery - IT. Available at:

http://www.sk.ru/Model/AboutFund/Clusters/IT.aspx [accessed 1 April 2012].

Skolkovo Foundation 2011b. Klastery - ladernye tekhnologii. Available at: http://www.sk.ru/Model/AboutFund/Clusters/Nuclear-Technology.aspx [accessed 1 April 2012].

Skolkovo Foundation 2011c. Usloviia arkhitekturnogo konkursa na razrabotku arkhitekturnykh kontseptsii zhilykh kvartalov planirovochnogo raiona 'Tekhnopark' Innovatsionnogo Tsentra "Skolkovo'. Moscow: Skolkovo Foundation.

Skolkovo Foundation 2012. Media Kit. Moscow: Skolkovo Foundation

Sum, N.-L. 2008. 'Neoliberalism and cultures of "competitiveness" in East Asia: numbers, clusters and chains', Memoirs of the Institute of Humanities and Social Sciences, 1: $137-145$.

True, J. 2005. 'Country before money: economic globalization and national identity in New Zealand', in E. Helleiner and A. Pickel (eds.), Economic Nationalism in a Globalizing World. Ithaca: Cornell University Press, pp. 202-219.

Vedomosti 2010a. 'Karikatura dnia', 22 April 2010.

Vedomosti 2010b. 'Nalogi otmeniaiutsia', 21 April 2010.

Vedomosti 2010c. 'Ot redaktsii: vybor sdelan', editorial, 15 Feburary 2010.

Vedomosti 2010d. 'Rossiia dlia umnykh', 5 May 2010.

Verdery, K. 1996. 'Whither "nation" and "nationalism"?' in G. Balakrishnan (ed.) Mapping the Nation. London: Verso. 
Vesti24 2010a. 'Rossiia budushchego nachnetsia so Skolkova', interview with Vladislav Surkov, 21 March 2010. Available at:

http://www.vesti.ru/doc.html?cid=58\&id=348506 [accessed 1 December 2011].

Vesti24 2010b. 'Vladislav Surkov: inzhener stanet glavnym chelovekom v strane', 21 March 2010. Available at: http://www.vesti.ru/doc.html?id=348492 [accessed 1 December 2011]. 